Original Research

\title{
Management of Shivering in Post-Spinal Anesthesia Using Warming Blankets and Warm Fluid Therapy
}

\section{Arina Qona'ah' ${ }^{1}$,Novi Enis Rosuliana², I Made Amartha Bratasena², and Wahyu Cahyono²}

${ }^{1}$ Faculty of Nursing, Universitas Airlangga, Surabaya, Indonesia

${ }^{2}$ Sekolah Tinggi Ilmu Kesehatan Mataram, Mataram, Indonesia

\begin{abstract}
Introduction: Hypothermia is a common and serious complication of spinal surgery and it is associated with many harmful perioperative outcomes. The aim of this study was to compare the effectiveness of warming blankets and warm fluid therapy to manage shivering.

Methods: A quasi-experiment with a non-equivalent control group was applied as the research design. There were 60 patients involved in the study. The instrument of this study was a warmer fluid modification, a warming blanket and a cotton blanket. The data was analyzed using an applied paired t-test and independent t-test.

Results: After 60 minutes of the intervention, the mean and SD of body temperature of the patients receiving warm fluids was $36.71 \pm 0.18$, a warming blanket was $36.12 \pm 0.35$, and the control group was $35.76 \pm 0.22$. The $\mathrm{p}$ values were 0,000 .

Conclusion: Warm fluid therapy and warming blankets are significant in terms of increasing the body temperature of post-spinal anesthesia patients. Warm fluids are more effective than warming blanket. Warming blankets and warm fluid therapy can be used as a way to increase the body temperature of patients with hypothermia.
\end{abstract}

\section{ARTICLE HISTORY}

Received: Dec 26, 2019

Accepted: Dec 31, 2019

\section{KEYWORDS}

Warm fluid therapy; warming blankets; hypothermia

\section{CONTACT}

Arina Qona'ah $\triangle$ arina-qonaah@fkp.unair.ac.id $\doteq$ Faculty of Nursing, Universitas Airlangga, Surabaya, Indonesia

Cite this as: Qona'ah, A.., Rosuliana, N.E., Bratasena, I.M.A \& Cahyono, W. (2019). Management of Shivering in Post-Spinal Anesthesia Using Warming Blankets and Warm Fluid Therapy. Jurnal Ners, Special Issues, 305-309. doi:http://dx.doi.org/10.20473/jn.v14i3.17166

\section{INTRODUCTION}

Hypothermia often occurs in postoperative patients. Around 40-60 minutes after anesthesia, the body temperature decreases intensively(Moysés, Trettene, Navarro, \& Ayres, 2014). Hypothermia occurs when the body temperature is less than $36^{\circ} \mathrm{C}$ at the perioperative point in time and during anesthesia. Hypothermia is caused by a cold operating room, decreased metabolism, the length and type of operation, body cavity exposure, the type of anesthesia and the fluids used in the operative processes(De Figueiredo Locks, 2012). Based on the results of a survey conducted on 564 patients, $45.7 \%$ experienced hypothermia(Aksu, Kus, Gurkan, Solak, \& Toker, 2014). Harahap (2014) said that the number of patients who experienced hypothermia in the recovery room was 113 people $(87.6 \%)$. In the patients receiving spinal anesthesia, the incidence rate of hypothermia was higher than that for general anesthesia (52\%)(Shaw, Steelman, DeBerg, \& Schweizer, 2017). Hypothermia is an independent factor in the occurrence of death due to interference various organs of the body and produce shivering in the post-operative period(Harahap, Kadarsah, \& Oktaliansah, 2014)(Okeke, 2007).

Hypothermia triggers shivering where oxygen demand increases 500\%(Zaman, Rahmani, Majedi, Roshani, \& Valiee, 2018). Shivering is the body's protection mechanism by increasing heat production through muscle contractions. Muscle contractions can increase heat production, oxygen consumption, and carbon dioxide production. This can lead to a risk of complications in patients with cardiovascular and pulmonary disorders(De Figueiredo Locks, 2012). Shivering occurs in $50 \%$ of operating patients with a body temperature of $35.5^{\circ} \mathrm{C}$ and $90 \%$ in patients with a body temperature of $34.5^{\circ} \mathrm{C}$ (Harahap et al., 2014). Shivering is more common in surgical patients who 
use spinal or epidural anesthesia(Tarmey \& White, 2009).

The intervention for the treatment of postoperative hypothermia is oxygen, intravenous thermal elements, warming blankets and wool caps. Therapy with warm fluids is given intravenously where previously the liquid is warmed to $37^{\circ} \mathrm{C}$. Warm fluids are used to reduce heat dissipation and to avoid iatrogenic cooling in the body(Nayoko, 2016). The active warming fluid infusion given to patients with spinal anesthesia has a significant impact on reducing the incidence of hypothermia and shivering(Sultan, Habib, Cho, \& Carvalho, 2015). Other than that, hypothermia can be controlled with active external installation. For example, a warming blanket. Warming blankets can protect the body after it has experienced hypothermia so then it is not exposed to the surrounding air which has a lower temperature(Jin \& Chung, 2001). During spinal anesthesia, giving the patient a passive warming (cotton blankets, reflective blankets) is less effective than active warming (forced air warming, underbody conductive heat mat, circulating water mattress, and a radiant warmer)(Shaw et al., 2017). A combination of several devices in managing the shivering can be more effective at controlling body temperature during the operative periods(Ihn et al., 2008). This study aims to determine the effectiveness of warm fluid therapy and warming blankets to increase body temperature in post-spinal anesthesia patients.

\section{MATERIALS AND METHODS}

The study design used in this study was a time series with a non-equivalent control group design with a population of 200 patients from October to November 2017.This research was conducted in the Recovery room of Yatofa Hospital. The inclusion criteria on this study were patient operatives who' had spinal anesthesia, aged from 18-65 years old and who experienced shivering. The total sample was 60 respondents divided into 40 respondents in the intervention groups divided into warm fluid therapy (infusion fluid warmed up to $37-40^{\circ} \mathrm{C}$ ) and a warming blanket. Meanwhile, 20 respondents in the control groups were given therapy according to the hospital procedures performed post-spinal anesthesia; a blanket was provided.

The instrument in this study was a warmed fluid infusion, a warmed blanket and a cotton blanket. For the warmed fluid infusion, we used a box of $27 \mathrm{~cm} \times 25 \mathrm{~cm} \times 40 \mathrm{~cm}$ with 800 grams weight, voltage 110 / 220 v equipped with 40 watt light bulbs (2 lamps). The specifications of the warmed blanket are that it was made from fine cotton and had a plain blue motif, while being $1 \mathrm{~kg}$ in weight, $150 \mathrm{~cm}$ in length, $2 \mathrm{~m}$ in width and with a thickness of $5 \mathrm{~cm}$. The body temperature measurements were taken using an axillary thermometer and observation sheet. The patient's body temperature was divided into four criteria; mild hypothermia $\left(32-36^{\circ} \mathrm{C}\right)$, moderate hypothermia $\left(28-32^{\circ} \mathrm{C}\right)$, severe hypothermia $\left(<28^{\circ} \mathrm{C}\right)$ and normal body temperature $\left(36-37,5^{\circ} \mathrm{C}\right)$. Body temperature measurements after the intervention were carried out four times, namely at the 15,30 , 45and 60minutes.

The collected data was analyzed using a paired $t$ test and independent t-test. The paired t-test was used to measured the differences before and after the treatment in the respective groups. To find out which treatment had the most influence on changes in body temperature, an independent t-test was conducted. This research was conducted by upholding ethical principles and getting approval from the research location.

\section{RESULTS}

The total patients used in this study were 60 patients. The patients were grouped into an intervention group and a control group. The intervention group was given warm fluids and warming blankets. The control group was given a blanket. The average age of the patients in this study was 41.8 years (41.8 in the warm fluid intervention group, 44.5 in the group treating with warming blankets and 39.10 in the control group). There were 28 male patients (46.7\%) and 32 female patients (53.3\%). The average body temperature of the patient before the intervention was $35.370 \mathrm{C}$ and body temperature after the intervention was $35.550 \mathrm{C}$ at 15 minutes, $35.790 \mathrm{C}$ at 30 minutes, $36.060 \mathrm{C}$ at 45 minutes and $36.170 \mathrm{C}$ at 60th minutes (Table 1). There was a significant difference in body temperature before and after the intervention in both the intervention and control groups ( $p$-value $<0.05$ ) (Table 2 ). The results of the independent $t$-test showed that there were significant temperature differences between the warm fluid and the warming blanket at 30, 45 and 60 minutes; at 30t and 45 minutes in the comparison between warm fluid and the control group and at 60t minutes at the and of the warm blanket and control group comparison (Table 3).

\section{DISCUSSION}

Shivering is part of the body's defense mechanism by regulating the center of heat in the body which can produce harmful effects in terms of systemic oxygen consumption, oxygen in the brain tissue and intracranial pressure. Spinal and general anesthesia can cause shivering. Spinal anesthesia causes heat redistribution from the center of the body to the periphery because spinal anesthesia induces vasodilation(A., 2017). A rapid decrease in core body temperature due to shifting body heat from the core to the perimeter can cause vasodilation. After that, the reduction slows down the core temperature, causing heat loss due to excessive heat production(Zaman et al., 2018). Hypothermia is more common in the elderly compared to adults. Based on the results of this study, $46.7 \%$ of patients who experienced hypothermia were aged 41-65 years, while those aged 18-25 years had an incidence rate of $13.3 \%$. In the elderly, spinal anesthesia causes hypothermia and 
slows recovery(Mendonça, Lucena, Quirino, Govêia, \& Guimarães, 2019). 
Table 1. Demographic data (mean \pm SD) of the patients shivering after spinal anesthesia

\begin{tabular}{|c|c|c|c|c|}
\hline \multirow[t]{3}{*}{ Variabel } & \multicolumn{3}{|c|}{ Groups (mean \pm SD) } & \multirow{3}{*}{$\begin{array}{l}\text { All respondents } \\
(\text { mean } \pm \text { SD) }\end{array}$} \\
\hline & \multicolumn{2}{|c|}{ Intervention } & \multirow[t]{2}{*}{ Control } & \\
\hline & Warm fluid & Warming blanket & & \\
\hline Patient age & $41,85 \pm 14,87$ & $44,55 \pm 12,28$ & $39,10 \pm 14,98$ & $41,83 \pm 14,04$ \\
\hline Patient sex & 10 (male) & 8 (male) & 10 (male) & 28 (male) \\
\hline & 10 (female) & 12 (female) & 10 (female) & 32 (female) \\
\hline $\begin{array}{l}\text { Body temperature } \\
\text { before intervention }\end{array}$ & $35.43 \pm 0.22$ & $35.34 \pm 0.26$ & $35.34 \pm 0.25$ & $35.37 \pm 0.24$ \\
\hline $\begin{array}{l}\text { Body temperature after } \\
15 \text { minutes }\end{array}$ & $35.67 \pm 0.22$ & $35.49 \pm 0.27$ & $35.49 \pm 0.26$ & $35.55 \pm 0.26$ \\
\hline $\begin{array}{l}\text { Body temperature after } \\
30 \text { minutes }\end{array}$ & $35.99 \pm 0.16$ & $35.68 \pm 0.27$ & $35.74 \pm 0.32$ & $35.79 \pm 0.30$ \\
\hline $\begin{array}{l}\text { Body temperature after } \\
45 \text { minutes }\end{array}$ & $36.35 \pm 0.18$ & $35.91 \pm 0.31$ & $35.96 \pm 0.42$ & $36.06 \pm 0.38$ \\
\hline $\begin{array}{l}\text { Body temperature after } \\
60 \text { minutes }\end{array}$ & $36.71 \pm 0.18$ & $36.12 \pm 0.35$ & $35.76 \pm 0.22$ & $36.17 \pm 0.48$ \\
\hline
\end{tabular}

Table 2. Test results of the paired t-test in shivering patients post-spinal anesthesia

\begin{tabular}{llccc}
\hline & & Mean \pm SD & CI 95\% & $\boldsymbol{P}$ \\
\hline Intervention & Before and after warm fluid for 15 minutes & $0.24 \pm 0,59$ & $0,21-0,26$ & 0,00 \\
group: warm fluid & Before and after warm fluid for 30 minutes & $0,56 \pm 0,11$ & $0,51-0,61$ & 0,00 \\
& Before and after warm fluid for 45 minutes & $0,93 \pm 0,16$ & $0,85-0,99$ & 0,00 \\
Intervention & Before and after warm fluid for 60 minutes & $1,28 \pm 0,26$ & $1,15-1,40$ & 0,00 \\
group: warming & Before and after warming blanket for 15 minutes & $0,15 \pm 0,06$ & $0,12-0,17$ & 0,00 \\
blanket & Before and after warming blanket for 30 minutes & $0,34 \pm 0,09$ & $0,29-0,38$ & 0,00 \\
& Before and after warming blanket for 45 minutes & $0,57 \pm 0,13$ & $0,50-0,63$ & 0,00 \\
Control group & Before and after warming blanket for 60 minute s & $0,77 \pm 0,18$ & $0,68-0,86$ & 0,00 \\
& Before and after blanket for 15 minutes & $0,14 \pm 0,24$ & $0,03-0,25$ & 0,015 \\
& Before and after blanket for 30 minutes & $0,39 \pm 0,34$ & $0,23-0,56$ & 0,00 \\
& Before and after blanket for 45 minutes & $0,62 \pm 0,43$ & $0,41-0,82$ & 0,00 \\
& Before and after blanket for 60 minutes & $0,41 \pm 0,35$ & $0,24-0,58$ & 0,00 \\
\hline
\end{tabular}

Table 3. The results of the independent $t$ test on shivering patients post-spinal anesthesia

\begin{tabular}{|c|c|c|c|c|}
\hline & & $\mathrm{n}$ & Mean \pm SD & $P$ \\
\hline \multirow{6}{*}{$\begin{array}{l}\text { Warm fluid } \\
\text { Thermal blanket }\end{array}$} & Before intervention & 20 & $35,43 \pm 0,22$ & 0,345 \\
\hline & \multirow{2}{*}{15 minutes after intervention } & \multirow[t]{2}{*}{20} & $35,67 \pm 0,22$ & \multirow[t]{2}{*}{0,156} \\
\hline & & & $35,49 \pm 0,27$ & \\
\hline & 30 minutes after intervention & 20 & $\begin{array}{l}35,99 \pm 0,16 \\
35,68 \pm 0,27\end{array}$ & 0,010 \\
\hline & 45 minutes after intervention & 20 & $\begin{array}{l}36,35 \pm 0,18 \\
35,91 \pm 0,31\end{array}$ & 0,004 \\
\hline & 60 minutes after treatment & 20 & $\begin{array}{l}36,71 \pm 0,18 \\
36,12 \pm 0,35\end{array}$ & 0,001 \\
\hline \multirow{5}{*}{$\begin{array}{l}\text { Warm fluid } \\
\text { Control }\end{array}$} & Before intervention & 20 & $\begin{array}{l}35,43 \pm 0,22 \\
35,34 \pm 0,25\end{array}$ & 0.579 \\
\hline & 15 minutes after intervention & 20 & $\begin{array}{l}35,67 \pm 0,22 \\
35,49 \pm 0,26\end{array}$ & 0.405 \\
\hline & 30 minutes after intervention & 20 & $\begin{array}{l}35,99 \pm 0,16 \\
35,69 \pm 0,34\end{array}$ & 0.025 \\
\hline & 45 minutes after intervention & 20 & $\begin{array}{l}36,35 \pm 0,18 \\
35,93 \pm 0,44\end{array}$ & 0.002 \\
\hline & 60 minutes after intervention & 20 & $\begin{array}{l}36,71 \pm 0,18 \\
35,70 \pm 0,18\end{array}$ & 1.000 \\
\hline \multirow[t]{5}{*}{$\begin{array}{l}\text { Warming blanket } \\
\text { Control }\end{array}$} & Before intervention & 20 & $\begin{array}{l}35,34 \pm 0,26 \\
35,34 \pm 0,25\end{array}$ & 0,701 \\
\hline & 15 minutes after intervention & 20 & $\begin{array}{l}35,49 \pm 0,27 \\
35,49 \pm 0,26\end{array}$ & 0,601 \\
\hline & 30 minutes after intervention & 20 & $\begin{array}{l}35,68 \pm 0,27 \\
35,69 \pm 0,34\end{array}$ & 0,705 \\
\hline & 45 minutes after intervention & 20 & $\begin{array}{l}35,91 \pm 0,31 \\
35,93 \pm 0,44\end{array}$ & 0,236 \\
\hline & 60 minutes after intervention & 20 & $\begin{array}{l}36,12 \pm 0,35 \\
35,70 \pm 0,18\end{array}$ & 0,001 \\
\hline
\end{tabular}


effectively than a warming blanket or cotton blanket. Warm fluids significantly controlled shivering after 30 minutes. All patients who were given warm fluids for 60 minutes experienced changes in their body temperature from hypothermia to normothermia. The warm liquid was given to the post-spinal anesthesia patients who experienced shivering and it worked through the mechanism of heat conduction. Warm liquids can increase the tolerance of the regulatory systems when shivering occurs. Warm fluids given through intravenous lines aim to maintain core body temperature by activating the reflex and semi-reflex thermoregulation mechanisms in humans so then there are otonomsomatic, endocrine and behavioral changes(Nayoko, 2016).

Giving a warming blanket to post-spinal anesthesia patients can increase the body temperature to normothermia in almost half (30\%) of the patients. Warming blankets can protect the body from exposure to low room temperatures. Giving blankets to post-operative patients can minimize body heat loss due to incision wounds and the effects of hypothermia during surgery. When the hypothermia of the body experiences vasoconstriction, this can cause a loss of heat so the blankets act as heat insulators to prevent excessive heat loss(Ihn et al., 2008). Blankets can be used to reduce cutaneous heat loss. A sheet of insulator (blanket) can reduced heat loss by 30\%(Lopez, 2018).

Maintaining hemodynamic stability during the perioperative period is important to ensure a balance between delivery and oxygen demand. In the early post-operative stage, mild hypothermia can increase the concentration of norepinephrine and peripheral vasoconstriction which contributes to cardiovascular ischemia and arrhythmias. Hypothermia also increases blood loss during surgical procedures, while also increasing the risk of infection, decreasing drug metabolism and causing prolonged hospitalization time(Jin \& Chung, 2001). The intervention that can be taken to maintain hemodynamic stability is the giving of warm fluids and warming blankets. The limitation of this research was that the instrument used to warm the fluid was still manual.

\section{CONCLUSION}

Shivering due to hypothermia in post-operative patients having used spinal anesthesia can be treated using warm fluids and warming blankets. Warm fluid therapy has proven to be more effective at boosting the body temperature to normal compared to a warming blanket. Controlling hypothermia should be carried out starting from the time that the patient is in the operating room and it should continue into the recovery room (perioperative). The management of hypothermia in postoperative patients can be done in a simple way. Nurses can use the available resources to make a tool that can be used to warm up intravenous fluids.

\section{REFERENCES}

A., P. (2017). Control of intraoperative shivering under spinal anaesthesia- A prospective randomized comparative study of butorphanol with tramadol. Journal of Krishna Institute of Medical Sciences University, 6(1), 57-65.

Aksu, C., Kus, A., Gurkan, Y., Solak, M., \& Toker, K. (2014). Survey on Postoperative Hypothermia Incidence In Operating Theatres of Kocaeli University. Turkish Journal of Anesthesia and Reanimation, 42(2), 66-70. https://doi.org/10.5152/tjar.2014.15010

De Figueiredo Locks, G. (2012). Incidence of Shivering after Cesarean Section under Spinal Anesthesia with or without Intrathecal Sufentanil: A Randomized Study. Revista Brasileira de Anestesiologia, 62(5), 676-684. https://doi.org/10.1016/S00347094(12)70166-6

Harahap, A. M., Kadarsah, R., \& Oktaliansah, E. (2014). The Incidence of Hypothermia and Duration of Care in the Recovery Room on Postoperative Geriatric Patients at Dr. Hasan Sadikin Hospital Bandung During October 2011-March 2012. Jurnal Anestesi Perioperatif, 2(1), 36-44.

Ihn, C. H., Joo, J. D., Chung, H. S., Choi, J. W., Kim, D. W., Jeon, Y. S., ... Choi, W. Y. (2008). Comparison of three warming devices for the prevention of core hypothermia and post-anaesthesia shivering. Journal of International Medical Research, 36(5), 923-931. https://doi.org/10.1177/1473230008036005 08

Jin, F., \& Chung, F. (2001). Minimizing perioperative adverse events in the elderly. British Journal of Anaesthesia, Vol. 87, pp. 608-624. https://doi.org/10.1093/bja/87.4.608

Lopez, M. B. (2018). Postanaesthetic shivering - from pathophysiology to prevention. Romanian Journal of Anaesthesia and Intensive Care, 25(1), 73-81.

https://doi.org/10.21454/rjaic.7518.251.xum

Mendonça, F. T., Lucena, M. C. de, Quirino, R. S., Govêia, C. S., \& Guimarães, G. M. N. (2019). Risk factors for postoperative hypothermia in the postanesthetic care unit: a prospective prognostic pilot study. Brazilian Journal of Anesthesiology, 69(2),

122-130. https://doi.org/10.1016/j.bjan.2018.10.001

Moysés, A. M., Trettene, A. dos S., Navarro, L. H. C., \& Ayres, J. A. (2014). Hypothermia prevention during surgery: Comparison between thermal mattress and thermal blanket. Revista Da Escola de Enfermagem, 48(2), 226-232. https://doi.org/10.1590/S0080623420140000200005

Nayoko. (2016). Perbandingan Efektifitas Pemberian Cairan. Jurnal Keperawatan Muhammadiyah, 1(1), 86-92.

Okeke, L. I. (2007). Effect of warm intravenous and irrigating fluids on body temperature during 
transurethral resection of the prostate gland. BMC Urology, 7, 5-7. https://doi.org/10.1186/1471-2490-7-15

Shaw, C. A., Steelman, V. M., DeBerg, J., \& Schweizer, M. L. (2017). Effectiveness of active and passive warming for the prevention of inadvertent hypothermia in patients receiving neuraxial anesthesia: A systematic review and metaanalysis of randomized controlled trials. Journal of Clinical Anesthesia, 38, 93-104. https://doi.org/10.1016/j.jclinane.2017.01.00 5

Sultan, P., Habib, A. S., Cho, Y., \& Carvalho, B. (2015). The Effect of patient warming during Caesarean delivery on maternal and neonatal outcomes: A meta-analysis. British Journal of Anaesthesia, Vol. 115, pp. 500-510. https://doi.org/10.1093/bja/aev325

Tarmey, N., \& White, L. A. (2009). Section 3: Shivering. In Risks associated with your anaesthetic (pp. 13).

Zaman, S. S., Rahmani, F., Majedi, M. A., Roshani, D., \& Valiee, S. (2018). A Clinical Trial of the Effect of Warm Intravenous Fluids on Core Temperature and Shivering in Patients Undergoing Abdominal Surgery. Journal of Perianesthesia Nursing, 33(5), 616-625. https://doi.org/10.1016/j.jopan.2016.12.010 